\title{
COMPARISON AMONG THREE TECHNIQUES IN THE PARASITOLOGICAL DIAGNOSIS OF Fasciola hepatica IN CATTLE
}

\author{
Anderson Silva Dias ${ }^{1}$, Jackson Victor de Araújoㄹ, Fábio Ribeiro Braga ${ }^{1}$, Odilon \\ Azevêdo Calian', Vinícius Longo Ribeiro Vilela ${ }^{2}$, Vinícius Zacarias Miranda' \\ 1 UFV \\ 2 UFCG \\ Correspondência: Anderson Silva Dias: andersonmedvet@hotmail.com
}

\begin{abstract}
Helminthosis are relevant because they are responsible by substantial economic losses. Many techniques have been developed to facilitate parasitological diagnosis and comparisons among these techniques are essential. The present work aimed a comparison among three techniques of quantitative sedimentation for parasitological diagnosis of Fasciola hepatica in cattle. The modified sedimentation techniques of Dennis, Stone \& Swanson (DSS), Girão and Ueno (quatro tamises - QT; four sieves) and Foreyt were compared using analysis of variance, linear regression and correlation tests. Evaluations of sensitivity, specificity and agreement were performed using the kappa test. It was found that the modified DSS technique had a high mean egg count and high sensitivity $(p<0.01)(48.60 \%)$. The three techniques showed a specificity of $100 \%$. There was no correlation among the values of egg count obtained by the three techniques, and significant coefficients were not observed by regression analysis. The egg count results of $F$. hepatica obtained by the techniques of quatro tamises and Foreyt showed excellent concordance by the kappa test. The modified DSS technique appeared to be the most effective for $F$. hepatica diagnosis in cattle $(p<0.01)$.
\end{abstract}

Key Words: parasitological diagnosis; sedimentation quantitative techniques; trematode; Fasciola hepatica; cattle

\section{COMPARAÇÃO ENTRE TRÊS TÉCNICAS NO DIAGNÓSTICO PARASITOLÓGICO DA Fasciola hepatica EM BOVINOS}

RESUMO: Helmintoses são relevantes porque são responsáveis por substanciais perdas econômicas. Muitas técnicas têm sido desenvolvidas para facilitar o diagnóstico parasitológico e comparações entre estas técnicas são essenciais. O presente trabalho teve como objetivo a comparação entre três técnicas quantitativas de sedimentação para o diagnóstico parasitológico de Fasciola hepatica em bovinos. As técnicas de sedimentação modificadas de Dennis, Stone \& Swanson (DSS), Girão e Ueno (Quatro tamises - QT) e Foreyt foram comparadas através de análise de variância, regressão linear e testes de correlação. As avaliações da sensibilidade, especificidade e concordância foram realizadas utilizando o teste kappa. Foi verificado que a técnica de DSS modificada teve uma maior média $(p<0,01)$ de contagem de ovos por gramas de fezes e uma maior sensibilidade $(48,60 \%)$. As três técnicas apresentaram especificidade de $100 \%$. Não houve correlação entre os valores de contagem de ovos obtidos pelas três técnicas, e coeficientes significativos não foram observados por análise de regressão. Os resultados da contagem de ovos de F. hepatica obtido pelas técnicas de tamises Quatro e Foreyt apresentaram excelente concordância pelo teste kappa. A técnica DSS modificada pareceu ser a mais eficaz para o diagnóstico de $F$. hepatica em bovinos $(p<0,01)$.

Palavras-chave: diagnóstico parasitológico; técnicas de sedimentação quantitativas; Trematoda;

Fasciola hepatica; bovino 


\section{INTRODUCTION}

\section{Fasciolosis caused by the} trematode Fasciola hepatica is a common zoonotic disease that affects cattle and sheep in endemic areas (Echevarria 2004; Faria et al. 2005) and is considered as an emerging disease by the World Health Organization (MasComa et al. 1999). According to Cringoli et al (2002); Faria et al. (2005), the economic losses caused by $F$. hepatica in cattle and sheep production are meaningful. Previous studies of prevalence indicate an increase in dispersion and incidence of this agent in endemic areas (Mas-Coma et al., 1999; Echevarria 2004; Dorchies 2007; Lima et al. 2009). These events probably are due to the dispersion of the intermediate hosts (lymnaeids aquatic mollusks) of this agent in some regions (Coelho; Lima 2003).

Because of chemical treatment to reduce the frequency of these agents among animals, the identification of this agent's presence in herds by parasitological examination of the animals' faeces is often masked, and early diagnosis is essential so that production losses are reduced. Diagnosis often occurs the animal's slaughter; however, parasitological techniques of counting eggs in faeces are the most widely used that anothers, because it is practical and inexpensive. However, according to Reichel (2002); Dorchies (2007), the sensitivity of the most commonly used parasitological techniques, such as the Dennis, Stone \& Swanson (DSS) method (Dennis et al. 1954) and that of Girão and Ueno (1985) (quatro tamises - QT; four sieves in portuguese), is around $30 \%$. Therefore, attempts to improve on existing techniques or their implementation and studies to review them would be very valuable.

Many efforts have been made to increase the sensitivity of these parasitological diagnostic techniques, since they are easy to perform and have very low cost, are carried out effectively and do not require expensive reagents, that increasing production costs. The present study aimed to compare the sensitivity of three sedimentation techniques for $F$. hepatica diagnosis in cattle faecal samples.

\section{MATERIAL AND METHODS}

\section{Collection of samples from animals}

A total of 12 animals crossbred with an average age of 2 years 3 months were reared in a paddock. These animals had been initially free of $F$. hepatica. These animals were previous tested through parasitological technique to detect $F$. hepatica eggs. All animals were purchased of a region free of $F$. hepatica. For 16 repetitions, fortnightly, during June to December 2010, faecal samples were collected directly from the animals' rectum with a plastic bag, chilled and then sent to the laboratory of Parasitology, Federal University of Viçosa, totalling 192 samples e 576 examinations. The fecal samples were collected from cattle that were being reared on a paddock in the farm located in Cachoeiro de Itapemirim City (Espírito Santo State), $20^{\circ} 40^{\prime} 60.00^{\prime \prime S}, 41^{\circ} 12^{\prime}$ $0.00^{\prime \prime W}$. The samples were subjected to three diagnostic techniques for $F$. hepatica, as described below. To each technique were used 2 grams of faeces.

Techniques used in parasitological diagnosis

Modified technique of Dennis, Swanson \& Stone by Belém et al. (1992)

Samples were subjected to a sedimentation technique modified by Belém et al. (1992) that was first described by Dennis, Stone and Swanson (Dennis et al. 1954), which aims to determine the presence and quantify eggs of $F$. hepatica through 
observation of the entire content filtered in 10x objective (100x increase).

\section{Girão-Ueno filtration and sieving technique}

The samples were also evaluated by the QT modified technique as described by Girão and Ueno (1985), in which methylene blue is added to the pellet in a Petri dish, and then the reading is performed in a stereomicroscope increased 50 times.

\section{Modified sedimentation technique}

This technique was described by Foreyt (2001), in which the sediment is poured into a Petri dish and examined under a light microscope with $5 x$ objective.

\section{Obtaiment of Fasciola hepatica adults}

After period experimental, slaughters of cattle present in experimental assay were accompanies. The liver were separated and specifically, the trematodes in biliar duct were collected and identified according to Foreyt (2001).

\section{Statistical analysis}

Data were compared for egg counts of $F$. hepatica per grams of faeces obtained from the modified techniques of DSS, QT and Foreyt. Statistical analysis was performed by variance analysis ( $F$ test) at the $1 \%$ and $5 \%$ levels of probability. Mean of quantitative factors were compared by the Tukey test at the levels of $1 \%$ and $5 \%$. Regression analysis was performed to identify the correlation among the results obtained by the three techniques. A test of sensitivity and specificity of the three techniques was performed. The kappa index was calculated to assess the degree of concordance of the presence of $F$. hepatica eggs in faecal samples through the modified techniques of DSS, QT, and the modified sedimentation of Foreyt. All the above statistical analyses were performed in the BioEstat 5.0 program (Ayres et al. 2007).

\section{RESULTS}

Figure 1 show mean and standard errors of egg count per grams of faeces through three techniques. Table 1 relates the number of adults of $F$. hepatica recovered in the bile duct of the animals after slaughter. In Table 2 displays the results of sensitivity testing of the three techniques for parasitological diagnosis. The three techniques showed $100 \%$ of specificity.

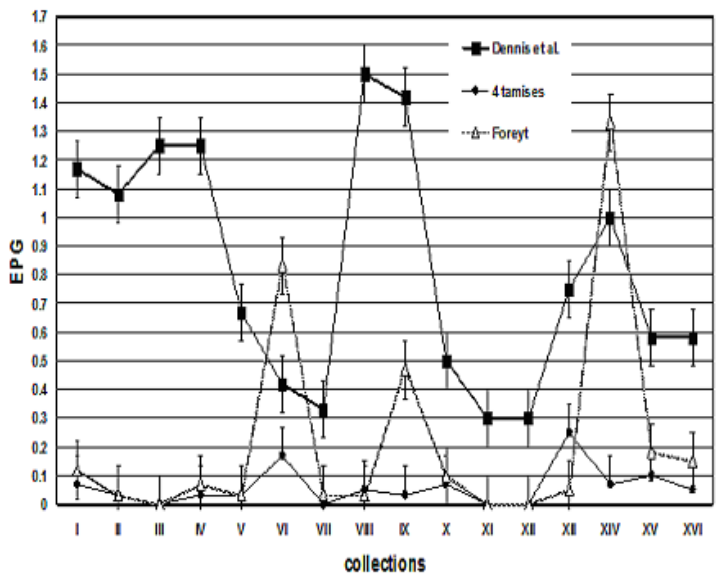

Figure 1 - Means and standard errors of counting Fasciola hepatica eggs per grams of faeces obtained by techniques of Dennis, Stone \& Swanson (Belém e al. 1992), quatro tamises (four sieves) (Ueno and Girão, 1982), and modified sedimentation of Foreyt (2001). Samples were collected from 12 bovines with 16 repetitions, fortnightly. These samples were collected fron these animals from June to December 2010. The experimental farm is located in the municipality of Cachoeiro de Itapemirim, Espírito Sant State, southeastern Brazil.

In the 16 different collections (192 samples) and examinations (576 through three techniques) of faecal samples performed, fortnightly, all animals showed to be positive count for $F$. hepatica. The modified technique of DSS had a mean of $0.82 F$. hepatica eggs per grams of faeces and it ranged of 1 to 14; QT gave a mean of 0.04 and it ranged of 1 at 12, and the modified sedimentation method of Foreyt showed a mean of 0.028 and it ranged of 1 at 16 . A different number of eggs $(p<0.01)$ was observed in the egg count obtained by the modified technique of DSS compared with counts obtained by the other two techniques. There were no differences between the count eggs 
obtained by the QT and modified Foreyt techniques ( $p>0.05)$.

The mean number of $F$. hepatica adults verified in biliar duct of slaughtered cattle was 1.75 , in three animals were not verified Fasciola in biliar duct, and in positive animals the presence of this agent ranged of 1 to 4 .

Table 1 - Number of Fasciola hepatica adults recovered from the bile ducts of cattle slaughtered after parasitological testing.

\begin{tabular}{cc}
\hline Animal & $\begin{array}{c}\text { Number of adult Fasciola hepatica found in the bile duct } \\
\text { after necropsy }\end{array}$ \\
\hline 01 & 2 \\
02 & 1 \\
03 & 2 \\
04 & 4 \\
05 & 0 \\
06 & 3 \\
07 & 2 \\
08 & 0 \\
09 & 3 \\
10 & 2 \\
11 & 2 \\
\hline
\end{tabular}

The correlation coefficients obtained in the linear regression showed no significance $(p>0.05)$; thus the count eggs obtained by the three techniques of quantitative sedimentation did not follow a competitor standard of distribution. A weak linear correlation was observed.

A higher sensitivity of the DSS technique $(48.60 \%)$ was verified, whereas the sensitivity obtained by the technique of QT was $15.30 \%$ and the modified sedimentation method of Foreyt was $20.80 \%$ (Table 2). The specificities of the three techniques were $100.00 \%$.

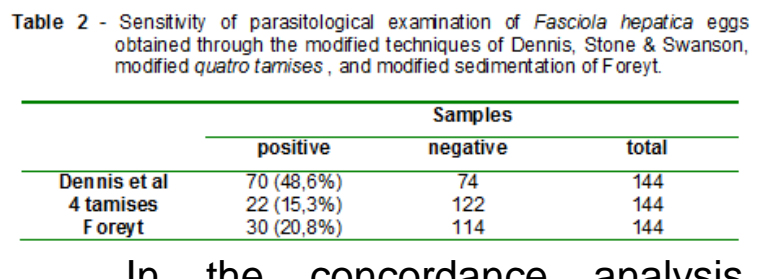

In the concordance analysis, there was a proportion value of 0.7865 among the modified sedimentation techniques of DSS and QT, a value of 0.7448 among the modified sedimentation techniques of DSS and Foreyt, and a value of 0.9583 among QT and Foreyt. The expected concordance values were $0.6009,0.6215$ and 0.7656 . The kappa index obtained to DSS and QT was 0.4549 (good replicability), to DSS and Foreyt was 0.3257 (weak) and to QT and Foreyt was 0.8222 (excellent).

\section{DISCUSSION}

When using the three techniques for counting $F$. hepatica eggs, low values of eggs count per grams of faeces were found, and the technique of DSS gave the highest average (0.82). In this work, a low number of adult parasites in the bile duct of animals and low egg count in faecal samples were verified, i.e. the results were as expected. After the slaughter of this animals, an average of 1.75 adults of $F$. hepatica per animal was observed. The low parasite load in the animals in this experimental assay may account for the low sensibility of the techniques to detect F. hepatica eggs by parasitological examination of faeces (Acha and Szyfres 2003).

Considering low number of adults in biliar duct of cattle in experiment, the percentual of $48.60 \%$ of positive samples obtained through of modified DDS technique compared to QT $(15.30 \%)$ and the modified sedimentation method of Foreyt $(20.80 \%)$. It can considering results obtained through this technique (DSS) as satistactory.

The technique of DSS possibly allowed the permanence of much debris at the bottom of the pellet, because the solution of aluminium potassium sulfate $\left(\mathrm{KAl}\left(\mathrm{SO}_{4}\right)_{2}\right)$ allows the sedimentation of less dense particles settling to the bottom of the cup. On the other hand, this method has the advantage of reduced losses of egg losses per faecal sample.

Mattos et al. (2009) compared the technique of Dennis et al. (1954) with the (unmodified) technique of QT (Girão and Ueno 1985). They observed that the (unmodified) QT technique showed higher sensitivity than the (unmodified) DSS technique, but using faecal 
samples from sheep. It should be emphasized that fasciolosis in cattle presents a profile of egg release different from that found in sheep. In cattle infected by $F$. hepatica, egg release is low compared with sheep and rodents (Cunha et al. 2007). Thus, under the conditions of the present study (for low parasite load), possibly the modified technique of DSS showed more reliable results.

Confirming the above proposal, Reichel (2002) states that in regions where the incidence of $F$. hepatica is low, the sensitivity of diagnostic faecal tests is low (around 30\%) in animals with low egg counts per grams of faeces. Anderson et al. (1999) reported a sensitivity of $66.70 \%$ for an egg-counting method, while the specificity was $100 \%$. However, this assay was carried out in a region where the animals were found to be infested with about 100 Fasciola adults in the bile ducts after slaughter, whereas in the present study the average adult parasite number was 1.75 , which probably contributed to the higher sensitivity than those obtained through the current work.

Thus, although modified QT and Foreyt techniques showed a close mean, the regression between the two mean presented a very small correlation coefficient, which actually demonstrates that these two techniques showed a concordance that was not significant.

Althought, the kappa index between DSS and QT is classified as good replicability; the kappa value of 0.8222 was considered excellent, when studying the comparison between the QT and Foreyt techniques. On the other hand, between DSS and Foreyt the concordance is weak.

It is proposed that with any of these three techniques, at least two replicates are carried out, as more reliable results can then be reported. The modified technique of DSS showed much greater sensitivity than the other two studied here, although it is low if compared with diagnosis by necropsy or even by slaughter; however, it allows early results and the indication of use of interventional measures.

Finally, when it is possible to compare the diagnostic techniques of $F$. hepatica in a quantitative manner in work in which QT and flukefinder techniques are compared, it is observed that there is no difference in results obtained quantitatively (Kleiman et al. 2005; Faria et al. 2005). Furthermore, Duménigo et al. (2000) report that the immunological techniques present more sensitivity; however, they fail to detect active infections and do not report the number of eggs or predict the number of adult parasites that produce them.

\section{CONCLUSION}

The modified technique of DSS showed greater sensitivity to identify cattle with $F$. hepatica infection than QT and Foreyt modified techniques.

\section{ACKNOWLEDGEMENTS}

The authors would like to thank Fapemig, CNPq, Capes and Capes/Finep for financial support and grant concession. We would also like to express gratitude to the farmer José Puppin for the supply of animals and for the use of his property.

\section{REFERENCES}

ACHA, P.N.; SZYFRES, B. Zoonoses and enfermidades transmissible common at human and animals. Pan American Health Organization. 3 ed. Washington, 2003.

ANDERSON, N.; LUONG, T.T.; VOA, N.G. et al. The sensitivity and specificity of two methods for detecting Fasciola infections in cattle.

Veterinary Parasitology, v.83, n.15, p.24, 1999. 
AYRES, M.; AYRES, J.R.M.; AYRES, D.L. et al. Aplicações estatísticas nas áreas de ciências biológicas. 5ed. Brasília, CNPq, 380 pp, 2007.

BELÉM, P.A.D.; OLIVEIRA, M.R. DE; PADOVANI, C.R. Adaptation of the Dennis, Stone \& Swanson's technique for parasitologic diagnostic of Eurytrema sp infection in cattle. Brazilian Journal of Veterinary Research and Animal Science, v.29, n.2, p.303-307, 1992.

COELHO, L.H.L.; LIMA, W.S. Population dynamics of Lymnaea columella and its natural infection by Fasciola hepatica in the State of Minas Gerais, Brazil. Journal of

Helminthology, v.77, n.1, p.7-10, 2003.

CRINGOLI, G.; RINALDI, L.; VENEZIANO, V. et al. A cross-sectional coprological survey of liver flukes in cattle and sheep from an area of the southern Italian Apennines. Veterinary Parasitology, v.108, p.137-143, 2002

CUNHA, F.O.V. DA; MARQUES, S.M.T.; MATTOS, M.J.T. DE. Prevalence of slaughter and liver condemnation due to Fasciola hepatica among sheep in the state of Rio Grande do Sul, Brazil 2000 and 2005. Parasitologia

Latinoamericana, v.62, n.3-4, p.188-191, 2007.

DENNIS, W.R.; STONE, W.M.; SWANSON, L.E. A new laboratory and field diagnostic test for fluke ova in feces. Journal American of the Veterinary Medical Association, v.124, n.922, p.47-50, 1954.

DORCHIES, P. Comparison of methods for the veterinary diagnosis of liver flukes (Fasciola hepatica) in cattle. Bulletin USAMV-CN, v.64, n.1-2, p.14-19, 2007.

DUMÉNIGO, B.E.; ESPINO, A.M.; FINLAY, C.M et al. Kinetics of antibody-based antigen detection in serum and faeces of sheep experimentally infected with Fasciola hepatica. Veterinary Parasitology, v.89, p.153-161, 2000.

ECHEVARRIA, F. Fasciolose. Rev Bras de Parasitol Vet, v.13, n.3, p.100-103, 2004.

FARIA, R.N.; CURY, M.C.; LIMA, W.S. Prevalence and dynamics of natural infection with Fasciola hepatica (Linnaeus, 1758) in Brazilian cattle. Revue Médicine Véterinary, v.156, n.2, p.85-86, 2005.

FOREYT, W.J. Veterinary Parasitology:

Reference Manual. 5th edition. Blackwell Publishing Professional, lowa, USA, 2001.
GIRÃO, E.S.; UENO, H. Técnica de Quatro tamises para o diagnóstico coprológico quantitativo de fasciolose em ruminantes.

Pesquisa Agropecuária Brasileira, v.20, n.8, p.905-912, 1985.

KLEIMAN, F.; PIETROKOVSKY, S.; GIL, S. et al. () Comparison of two coprological methods for the veterinary diagnosis of fasciolosis.

Arquivo Brasileiro de Medicina Veterinária e Zootecnia, v.57, n.2, p.181-185, 2005.

LIMA, W. DOS, S.; SOARES, L.R.M.; BARÇANTE, T.A. et al. Occurrence of Fasciola hepatica (Linnaeus, 1758) infection in Brazilian cattle of Minas Gerais, Brazil. Revista Brasileira de Parasitologia Veterinária, v.18, n.2, p.2730, 2009.

MAS-COMA, M.S.; ESTEBAN, J.G.F.; BARGUES, M.D. Epidemiología de la fascioliasis humana: revisión y propuesta de nueva classificación. Bulletin of the World Health Organization, v.77, n.4, p.340-346, 1999.

MATTOS, M.J.T. DE; CUNHA, F.O.V. DA; MARQUES, S.M.T. Comparação de duas técnicas parasitológicas na identificação de ovos de Fasciola hepatica. Revista da Faculdade de Zootecnia, Veterinária e Agronomia, Uruguaiana, v.16, n.1, p.105-112, 2009.

REICHEL, M.P. Performance characteristics of an enzyme-linked immunosorbent assay for the detection of liver fluke (Fasciola hepatica) infection in sheep and cattle. Veterinary Parasitology, v.107, p.65-72 2002. 